\title{
Variations in the Physicochemical Profile of Khushab Coal under Various Environmental Conditions
}

\author{
Nyla Amjed ${ }^{1}$, Ijaz Ahmad Bhatti', Khalid Arif ${ }^{2}$, Munawar Iqbal ${ }^{3 *}$, \\ Arif Nazir $^{3 * *}$, Muhammad Zahid ${ }^{1}$ \\ ${ }^{1}$ Department of Chemistry, University of Agriculture, Faaisalabad, Pakistan \\ ${ }^{2}$ Department of Mathematics and Statistics, University of Lahore, Lahore, Pakistan \\ ${ }^{3}$ Department of Chemistry, University of Lahore, Lahore, Pakistan
}

Received: 21 March 2017

Accepted: 22 April 2017

\begin{abstract}
This work illustrates the proximate analysis on three types of coal samples obtained from Khushab mines in Pakistan. Analysis of the coal matrix was carried out to determine volatile matter, ash contents, moisture, fixed carbon contents, calorific values, and sulfur contents as per standards of American Society for Testing and Materials (ASTM). The results of proximate analysis show 30.46\% fixed carbon content, $28.08 \%$ ash content, $6.96 \%$ total moisture content, and $34.5 \%$ volatile matter within sample A, whereas $40.56 \%$ volatile matter, $8.03 \%$ moisture content, $8.32 \%$ ash and $30.46 \%$ fixed carbon content was found in sample B. Sample C contained $15.44 \%$ volatile matter, $9.16 \%$ moisture content, $40.64 \%$ ash content, and $37.5 \%$ fixed carbon content, respectively. Sample B has higher calorific value and sulphur contents in comparison to A and C. These coal samples are of good quality from an industrial prospective, but they need to be desulphurized prior to industrial use for the sake of the environment.
\end{abstract}

Keywords: proximate, coal, fixed carbon, volatile matter, moisture, ash contents

\section{Introduction}

Emissions of hazardous materials like methane, carbon monoxide, sulphur, and coal dust during the mining process posed severe environmental problems [14]. Non-implementation of environmental standards is a major cause of these enhanced effluents. The incidence of sulphur in the coal matrix is responsible for acidic contents

*e-mail: anmalik77@gmail.com

**e-mail: Iqbal, munawar.iqbal@chem.uol.edu.pk of underground water. Effective greenhouse gases released into the air are a major source of global warming and acid rain. Negative changes to the environment caused by the coal mining process include severe damage to waterways due to the sulphurous contents of mined material. The concerns of such activities have resulted in the alteration in atmospheric settings that eventually affect climatic conditions globally [5-20].

The composition and structure of coal consists of carbon mixed with hydrogen-containing impurities. The presence of benzene tri-, tetra-, and complex waxy material indicates the preponderance of aromatic structures. The topological indices are often used to model 
the physicochemical properties of chemical compounds (coal) in quantitative structure-property relation (QSPR) and quantitative structure-activity relation (QSAR) studies [19-21]. The advantage of topological indices is that they may be used directly as simple numerical descriptors in a comparison with physical, chemical, or biological parameters of molecules in QSPR and in QSAR. For example, the Wiener index [22] correlates well with many physicochemical properties of organic compounds and as such has been well studied over the last quarter of a century. Reverse Wiener index [23] is used to produce QSPR models for hydrocarbon molar heat capacity. Coal is classified or ranked (Table 1) in various categories according to degree of metamorphism of plant material. Metamorphism reduces moisture, hydrogen, and oxygen content while enhancing the percentage of carbon content.

Proximate analysis is frequently used for characterizing coal in connection with their utilization. A typical proximate analysis includes the moisture, ash, volatile matter, and fixed carbon content. Moisture content affects the energy value of the coal as an increase in moisture content decreases the calorific value of the coal [24]. Ash content represents the bulk mineral matter after carbon, oxygen, sulfur, and water have been driven off during combustion [25].

Volatile matter in coal refers to the components of coal (except for moisture) that are liberated at high temperature in the absence of air. It is derived from organic and mineral matter in coal. These contents determine the combustible ability of coal samples. During combustion of coal samples, mineral matter ignites to generate combustible volatiles, thus affecting the performance of coal, whereas organic matter upon combustion liberates products such as oils, oxides of carbon, hydrogen, tar, and hydrocarbon gases. Fixed carbon content of the coal is the carbon found in material that is left after volatile matters are driven off. The value of fixed carbon contents is only useful when we compare the different qualities of coal.

The presence of sulphur in coal causes significant environmental hazards and serious problems in its utilization [27]. It is present in both organic and inorganic form, the former being more probable to be structurally integrated into a macromolecular organic matrix for fuels [28]. The organic form has a greater proportion of thiophenic Sulphur, which degrades slowly and becomes carcinogenic more than polyaromatic hydrocarbons and nitrogenous compounds [29-30].

Anthracite is the highest metaphorrphically ranking coal consisting of $87 \%$ carbon contents on a dry ash-free basis. It is also known as hard coal and is characterized by brilliant luster, and is hard and shiny in appearance. Anthracite is further subdivided into semi-anthracite, meta-anthracite, and anthracite on the basis of carbon contents [31-32]. Bituminous coal is the highest ranking coal, consisting of $15-20 \%(\mathrm{w} / \mathrm{w})$ volatile matter and is known as soft coal. It has heating value much higher than that of lignite or subbituminous coal. It has carbon contents of $77-87 \%$ on dry ash free basis. On the basis of heating values, it is further subdivided into sub-bituminous $\mathrm{A}, \mathrm{B}$, and $\mathrm{C}$ ranks. It can be characterized as highly volatile, medium volatile, or low volatile bituminous on the basis of volatile matter contents.

Sub-bituminous coal is a glossy-black weathering coal with increased level of metamorphism. Carbon contents of sub-bituminous coal vary from 71 to $77 \%$ on a dry ashfree basis. Further sub-bituminous coal is classified into three categories $-\mathrm{A}, \mathrm{B}, \mathrm{C}-$ on the basis of heating values

Table 1. ASTM classification of coal (modified after Wood et al. [26]).

\begin{tabular}{|c|c|c|c|c|c|c|c|}
\hline \multirow{2}{*}{ Class } & \multirow{2}{*}{ Group } & \multicolumn{2}{|c|}{ Fixed Carbon Contents (\%) } & \multicolumn{2}{|c|}{ Volatile Matter (\%) } & \multicolumn{2}{|c|}{ Calorific Value $(\mathrm{KJ} / \mathrm{Kg})$} \\
\hline & & $\geq$ & $<$ & $>$ & $\leq$ & $\leq$ & $<$ \\
\hline \multirow{3}{*}{ Anthracite } & Meta-anthracite & 96 & & & 2 & & \\
\hline & Anthracite & 92 & 98 & 2 & 8 & & \\
\hline & Semi-anthracite & 86 & 92 & 8 & 14 & & \\
\hline \multirow{5}{*}{ Bituminous } & Low Volatile & 78 & 86 & 14 & 22 & & \\
\hline & Medium Volatile & 69 & 78 & 22 & 31 & & \\
\hline & High Volatile A & & 69 & 31 & & 32,600 & \\
\hline & High Volatile B & & & & & 30,200 & 32,600 \\
\hline & High Volatile C & & & & & 26,700 & 30,200 \\
\hline \multirow{3}{*}{ Sub-bituminous } & Sub-bituminous A & & & & & 24,400 & 26,700 \\
\hline & Sub-bituminous B & & & & & 22,100 & 24,400 \\
\hline & Sub-bituminous C & & & & & 19,300 & 22,100 \\
\hline \multirow{2}{*}{ Lignite } & Lignite A & & & & & 14,700 & 19,300 \\
\hline & Lignite B & & & & & & 14,700 \\
\hline
\end{tabular}


[33]. Lignite is a brownish-black woody-structured coal and is lowest in rank, sometimes characterized with plant structure. On a free dry ash basis it has carbon contents between $60 \%$ and $70 \%$. Lignite is further subdivided in to two groups: lignite A, ranging from 6,300 to 8,300 BTUs and lignite B, with less than 6,300 BTUs [33]. According to ASTM, coal is classified as high or low rank on the basis of its calorific value (CV). It is a measure of heat produced per unit mass of material during combustion and is termed as enthalpy of combustion or specific energy. Calorific value is associated with bond energy between the atoms and is accurately determined from elementary composition [34].

\section{Materials and Methods}

The coal samples were passed through a $250 \mu \mathrm{m}$ (60-mesh) sieve and moisture content was determined by measuring weight loss of the sample. The $1 \mathrm{~g}$ coal sample is maintained under controlled conditions in an inert environment at $107 \pm 3^{\circ} \mathrm{C}$ for about one hour according to the ASTM D-3173 [35] method for moisture analysis in the sample of coal and coke. $1 \mathrm{~g}$ of coal sample is passed through pre-weighed platinum crucible with a closefitting cover was suspended in a furnace chamber at a specific height as per ASTM D-3175 [36]. In the furnace chamber the temperature of the furnace was maintained at $950 \pm 20^{\circ} \mathrm{C}$. The rapid discharge of volatile matter was evidence by the disappearing luminous flame, which in turn causes the lid to uncover against the pressure of air inside so that it must be sealed properly. After heating for seven minutes the crucible was removed from the furnace and subjected to cooling. The crucible should be weighed as soon as it is cold. The percentage moisture subtracted from the percentage loss of weight gives us the volatile matter. According to the ASTM D-3174 [37] standard test method, mineral and ash contents in coal samples were determined by heating at temperatures in the range 700 to $750^{\circ} \mathrm{C}$ for four hours.

After the removal of volatile matter, moisture and ash contents the left over solid combustible material in coal represents fixed carbon value. It is a measure of the solid combustible material that remains after the volatile matter in coal has been removed. Fixed-carbon values were analyzed on the basis of dry, free mineral matter according to ASTM D-388 [38]. A bomb calorimeter was used to estimate calorific values of coal using ASTM D-2015 [39], and the Eschka method (ASTM D-3177) [40] was used to determine total sulphur content. $1 \mathrm{~g}$ of coal sample was thoroughly mixed with $3 \mathrm{~g}$ of Eschka mixture, which is a combination of two parts by weight of light calcined magnesium oxide with one part of anhydrous sodium carbonate. The combination was placed in a porcelain crucible $(30 \mathrm{~mL})$ and covered with another gram of Eschka mixture. The crucible was placed inside a muffle furnace for oxidation at $800 \pm 25^{\circ} \mathrm{C}$. During combustion liberated sulfur compounds react with magnesium oxide and sodium carbonate, and under oxidizing conditions are retained as magnesium sulfate and sodium sulfate. The sulfate in the residue is extracted and determined gravimetrically.

\section{Results}

Proximate analysis was employed for evaluation and complete characterization of coal samples. Figs 1(a-c) show proximate analysis in terms of the weight percentages of ash contents (AC), fixed carbon contents (FCC), total moisture content (TMC), and volatile matter (VM). Samples A, B, and C showed moisture content, which was $6.96 \%, 8.03 \%$, and $9.16 \%$, respectively, of total sample weight. Sample A showed lower moisture content. Volatile matter in samples A, B, and C by weight of samples is $28.08 \%, 18.32 \%$, and $15.44 \%$, respectively. The ash content for samples $\mathrm{A}, \mathrm{B}$, and $\mathrm{C}$ are in the range of $34.49 \%, 40.56 \%$, and $40.64 \%$, respectively. Sample A has a low value of ash content as compared to samples $\mathrm{B}$ and $\mathrm{C}$, and fixed carbon content can be calculated by subtracting the amount of ash and volatile matter from 100 . These are found in the range of $33.94 \%, 33.99 \%$, and $37.50 \%$ for samples $\mathrm{A}, \mathrm{B}$, and $\mathrm{C}$, respectively. The results of proximate analysis of samples $\mathrm{A}, \mathrm{B}$, and $\mathrm{C}$ are given in Table 2. The calorific values of coal samples were also evaluated for complete characterization. Sample C

Table 2. Proximate analysis for coal samples A, B, and C.

\begin{tabular}{|c|c|c|c|}
\hline Analysis & Sample A (ar $\left.{ }^{\mathrm{a}}\right)$ & Sample B (ar) & Sample C (ar) \\
\hline Moisture content (wt. \%) & $6.96 \pm 0.14$ & $8.03 \pm 0.16$ & $16.44 \pm 0.18$ \\
\hline Volatile matter (wt. \%) & $28.08 \pm 0.69$ & $18.32 \pm 0.5496$ & $40.64 \pm 0.15$ \\
\hline Ash (wt. \%) & $34.49 \pm 0.56$ & $40.56 \pm 0.81$ & $37.5 \pm 0.75$ \\
\hline Fixed carbon (wt. \%) & $33.94 \pm 0.68$ & $33.99 \pm 0.68$ & 6.42 \\
\hline Total sulphur content (wt. \%) & 3.49 & 7.13 & 5,099 \\
\hline Calorific values (cal/g) & 6,253 & 5,730 & Sub-bituminous A \\
\hline Rank of coal & Sub-bituminous C & Sub-bituminous B & \\
\hline
\end{tabular}

${ }^{a} a r=$ as received basis (the samples were not processed — these are raw samples) 

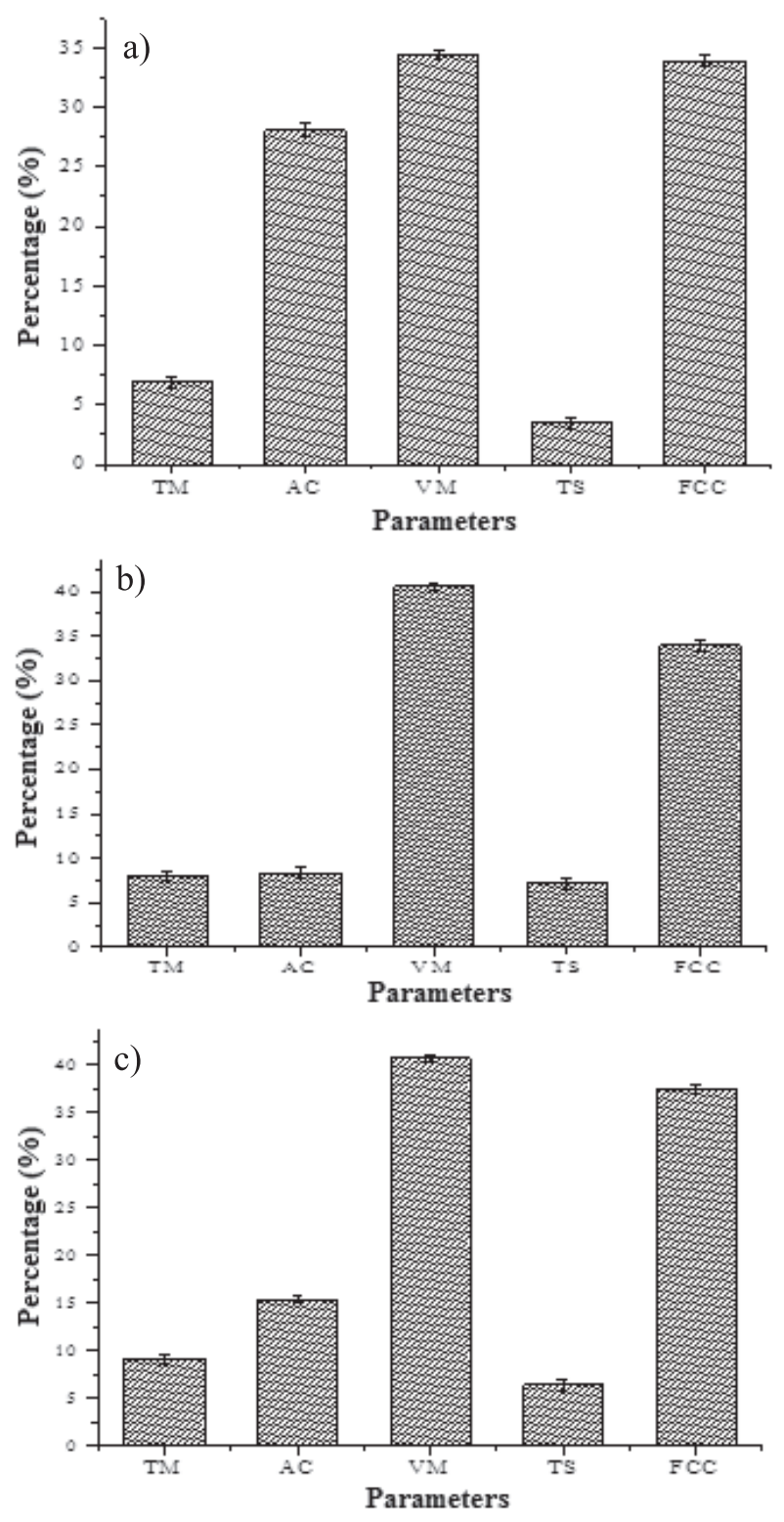

Fig. 1. Proximate analysis of coal samples (TM: total moisture; AC: ash content; VM: volatile matter; TS: total sulphur; FCC: fixed carbon contents).

has maximum calorific value of $6,253 \mathrm{Cal} / \mathrm{g}$ of the coal sample with the highest fixed carbon content. Sample B has a higher fixed carbon value with a calorific value of 5,730 Cal/g less than $\mathrm{C}$, whereas sample A has the lowest calorific value of 5,099 Cal/g as compared to B and C.

\section{Discussion}

The basic idea behind the present research was to analyze and characterize the quality of coal in the area of Khushab District in Punjab, Pakistan. Previous studies revealed that coal-burning properties depend on coal quality, and that under different environment conditions [41-48], the properties may vary. In the present investigation the variation in moisture content, volatile matter, fixed carbon content, calorific value, and sulphur contents was observed in coal collected from different locations in the Khushab area. The analysis was carried out on an as-received basis. The calorific value of coal is significantly affected by moisture content. The increase in moisture content decreases the calorific value of coal because considerable heat is required to evaporate the moisture [24]. The less moisture content, the better coal quality [49-50]. Sample A showed the lower moisture contents compared to other samples. Samples B and C showed that volatile matter contents are on the lower side compared to sample A. The typical range of volatile matter is $20-35 \%$. Except for the moisture liberated at high temperature in the absence of air, all components of coal refer to volatile matter. The amount of volatile combustible matter contributes to the heating value of coal, and higher values indicate easy ignition of fuel.

High ash contents are not approved as they may cause a deleterious effect on coal utilization processes. This may cause a poisoning effect and passivate the catalyst $[49,51-$ 53]. Sample A has low value of ash content as compared to samples B and C. Typically, ash content is found in the range of $5-40 \%$. High volatile matter and ash content are significant for designing the furnace; combustion volume, ash handling system, and pollution control. Fixed carbon refers to the carbon present in a free state in the coal matrix. Carbon contents of coal upon combustion produce heating. The typical range for fixed carbon is $23-$ $67 \%$. Coal samples were of low rank with high sulphur content as the analysis results demonstrated in Table 2. The typical sulphur content range is $0.15-4.67 \%$. Sample A has low sulphur content so it is considered better for combustion processes, particularly from an industrial point of view. The possibility of producing toxic oxides will accordingly be reduced with low sulphur content [4548].

Sample B showed a high level of total sulphur content near the possible limits reported (10\%) of the sulphur present in coal [55]. The calorific values of coal samples were also evaluated for complete characterization. Coal samples can be characterized by their calorific value according to the ASTM-388 characterization chart of coal, and proximate analysis showed that the values of carbon contents lie on the lower sides. The fixed carbon acts as a main heat generator during combustion $[49,54]$. Therefore, it is important to study coal quality under different environmental conditions, and it was observed that quality was variable.

Sample A has maximum calorific value among coal samples with the highest fixed carbon content, whereas sample $\mathrm{C}$ has the lowest calorific value compared to $\mathrm{B}$. This is due to an increase in moisture content in samples $\mathrm{B}$ and $\mathrm{C}$. Calorific value characterized the coal into ranking categories of $\mathrm{A}, \mathrm{B}$, and $\mathrm{C}$ according to (ASTM388) [38], with sample A ranked as sub-bituminous coal in category $\mathrm{C}$, whereas sample $\mathrm{B}$ is sub-bituminous coal of rank $\mathrm{B}$, and sample $\mathrm{C}$ is in the rank of sub-bituminous A. Typically, calorific values of coal lie in the range of 
13.87-32.08 MJ/Kg. Implementation regarding calorific value is not suitable for industrial applications because it is not useful for plant equipment and the environment, which is a serious issue [56-63].

\section{Conclusions}

Proximate analysis was performed to assess the quality of coal obtained from Khushab mines in Pakistan. For good coal quality, it should have low moisture, low ash, high volatile material, high calorific value, and high fixed carbon contents. The data revealed Sample A's rank in sub-bituminous class C, Sample B in sub-bituminous class $B$, and sample $\mathrm{C}$ in class A. From the calorific value it is observed that higher sulphur contents and fixed carbon content were observed in sample B in comparison with samples A and C. Sample A could be better industrial fuel. It is concluded that all these samples must be desulphurized prior to use for any industrial process.

\section{References}

1. AZAD S. Environmental degradation due to coal mining in Baluchistan. Pol. J. Environ. Stud. 24, 4, 1815, 2015.

2. JENDRUS R. Environmental Protection in Industrial Areas and Applying Thermal Analysis to Coal Dumps. Pol. J. Environ. Stud. 26 (1), 137, 2017.

3. MOLANDA T. Physical-Chemical Properties of Coal Mine Waters of Old Adits and Spring Waters. Pol. J. Environ. Stud. 23 (2), 393, 2014.

4. POMYKAŁA R., MAZURKIEWICZ M. Properties of Coal Gasification Wastes Essential to Determining Their Impact on the Environment. Pol. J. Environ. Stud. 24 (5), 2147, 2015

5. FAN J., WANG Y. Atmospheric Emissions of As, Sb, and Se from Coal Combustion in Shandong Province, 20052014. Pol. J. Environ. Stud. 25 (6), 2339, 2016.

6. STROZIK G., JENDRUS R., MANOWSKA A., POPCYZK M. Mine Subsidence as a Post-Mining Effect in the Upper Silesia Coal Basin. Pol. J. Environ. Stud. 25 (2), 777, 2016.

7. CEICKO Z., ZOLNOWSKI A.C., MADEJ M., WASIAK G., LISOWSKI J. Long-Term Effects of Hard Coal Fly Ash on Selected Soil Properties. Pol. J. Environ. Stud. 24 (5), 1949, 2015.

8. BABARINDE A., ONYIAOCHA G.O. Equilibrium sorption of divalent metal ions onto groundnut (Arachis hypogaea) shell: kinetics, isotherm and thermodynamics. Chem. Int. 2, 37, 2016.

9. BOSAK M., HAJDUOVA Z., MAJERNIK M., ANDREJOVSKY P. Experimental-Energy Combustion of Biomass Combined with Coal in Thermal Power Plants. Pol. J. Environ. Stud. 24 (4), 1517, 2015.

10. IQBAL M., KHERA R.A. Adsorption of copper and lead in single and binary metal system onto Fumaria indica biomass. Chem. Int. 1, 157b, 2015.

11. JAFARINEJAD S. Control and treatment of sulfur compounds specially sulfur oxides (SOx) emissions from the petroleum industry: a review. Chem. Int. 2, 242, 2016.

12. JAMAL M.A., MUNEER M., IQBAL M. Photo-degradation of monoazo dye blue 13 using advanced oxidation process. Chem. Int. 1, 12, 2015.
13. STANISZEWSKI R. Heavy Metals in Waters and Sediments of Rivers Affected by Brown Coal Mine Waters. Pol. J. Environ. Stud. 23 96), 2217, 2014.

14. TRYBALSKI K., KEPYS W., KRAWCZYKOWSKI D., KRAWCZKOWSKA A., SZPONDER D. Physical Properties of Ash from Co-Combustion of Coal and Biomass. Pol. J. Environ. Stud. 23 (4), 1433, 2014.

15. QURESHI K., AHMAD M., BHATTI I., IQBAL M., KHAN A. Cytotoxicity reduction of wastewater treated by advanced oxidation process. Chem. Int. 1, 53, 2015.

16. KALEMBKIEWICZ J., CHMIELARZ U. Effects of Biomass Co-Combustion with Coal on Functional Speciation and Mobility of Heavy Metals in Industrial Ash. Pol. J. Environ. Stud. 22 (3), 741, 2013

17. CHMURA D., MOLENDA T., BLONSKA A., WOZNIAK G. Sites of Leachate Inflows on Coalmine Heaps as Refuges of Rare Mountainous Species. Pol. J. Environ. Stud. 20 (3), $551,2011$.

18. ERDOGAN S., BAYSAL A., AKBA O., HAMAMCI C. Interaction of Metals with Humic Acid Isolated from Oxidized Coal. Pol. J. Environ. Stud. 16 (5), 671, 2007.

19. DEVILLERS J., BALABAN A.T. (Eds.), Topological Indices and Related Descriptors in QSAR and QSPR, Gordon and Breach, Amsterdam, 1999.

20. DIUDEA M.V. (Ed.), QSPR/QSAR Studies by Molecular Descriptors, Nova, Huntington, 2001.

21. GUTMAN I., FURTULA B. (Eds.), Novel Molecular Structure Descriptors Theory and Applications vols. I-II, Univ. Kragujevac, Kragujevac, 2010.

22. TRINAJSTIC N. Chemical Graph Theory, Volume II, CRC Press, Inc., Boca Raton, Florida, 1983.

23. YUAN Y., ZHOU B., TRINAJSTIC N. On Reciprocal reverse Wiener index. J. Math. Chem. 2009.

24. THOMAS L. Handbook of practical coal geology. New York, John Wiley and Sons, 338, 1992.

25. GIVEN P.H., YARZAB R.F. Analysis of the organic substance of coals: problems posed by the presence of mineral matter. Anal. Methods for Coal \& Coal Prod. 2, 3, 1978.

26. WOOD G.H., KEHN T.M., CARTER D.M., CULBERTSON W.C. Coal resource classification system of the U.S. Geological Survey. Geological Survey Circular 891, United States Geological Survey, Denver, 1983.

27. MARINOV S.P., STEFANOVA M., STAMENOVA V., CARLEER R., YPERMAN J. Sulphur functionality study of steam pyrolyzed "Mequinenza" lignite using reductive pyrolysis technique coupled with MS and GC/MS detection systems. Fuel Proc. Technol. 86, 523, 2005.

28. OLIVELLA M.A., PALACIOS J.M., VAIRAVAMURTHY A., DEL RIO J.C., DE LAS HERAS F.X.C. A study of sulphur functionalities in fossil fuels using destructive (ASTM and Py-GC-MS) and non-destructive (SEM-EDX, XANES and XPS) techniques. Fuel. 81, 405, 2002.

29. ZHOU A.N., MA X.L., SONG C.S. Liquid-phase adsorption of multi-ring thiophenic sulfur compounds on carbon materials with different surface properties. J. Phys. Chem. B. 110, 4699, 2006

30. RAHIMEH N.F., SAEID A. Removal of thiophenic compounds from liquid fuel by different modified activated carbon cloths. Fuel Proc. Technol. 93, 45, 2012.

31. CHAKRAVORTY R.N. Coal research laboratories, Canada centre for mineral and energy Technology, Ottawa, Ontario, Canada, 84, 1984.

32. CHAKRAVORTY R.N., KAR K. Coal research laboratories, Canada Centre for mineral and energy Technology, Ottawa, Ontario, Canada, 86, 1996. 
33. SPEIGHT G.J. Handbook of Coal analysis. John willey and sons, 166, 2005.

34. VAN, KREVELIN, D.W., SCHUYER, J. Coal Science: Aspects of Coal Constitution. Elsevier, Amsterdam, Netherlands, 1993.

35. ASTM D-3173 Standard method for moisture analysis in sample of coal and coke .

36. ASTM D-3175 Standard Method of Test for volatile matter of Coal.

37. ASTM D-3174 Standard Method of Test for ash contents of Coal.

38. ASTM D-388 Standard Classification of Coals by Rank

39. ASTM D-2015 Standard Methods for Designating the Size of Coal from Sieve Analysis .

40. ASTM D-3177 Standard Test Methods for Total Sulphur Analysis in coal and coke.

41. XUAN L., WENKAI L., HEBING Z., HAIPENG N. Comprehensive Landscape Ecology Stability Assesment of a Coal Gangue Backfi II Reclamation Area. Pol. J. Environ. Stud. 25 (3), 1305, 2016.

42. GE X., MA J., CHANG L., YUAN J., SU X., WANG H., XIAO Y. Monitoring and Investigation Methane Leakage in Coal Gas Production. Pol. J. Environ. Stud. 25 (3), 1005, 2016 .

43. SAUER P., FIALA P., DVORAK A., KOLINSKY O., PRASEK J., FERBAR P., REDERER L. Improving Quality of Surface Waters with Coalition Projects and Environmental Subsidy Negotiation. Pol. J. Environ. Stud. 24 (3), 1299, 2015.

44. SAKOL G., MIROSLASKI J., BREWCZYNSKI P.Z. Efficient $\mathrm{Pb}$ Translocation by Purple petticoats cv. of Heuchera L. from Contaminated Soil in a Coal Basin. Pol. J. Environ. Stud. 23 (6), 2199, 2014

45. KIERCZAK J., CHUDY K. Mineralogical, Chemical, and Leaching Characteristics of Coal Combustion Bottom Ash from a Power Plant Located in Northern Poland. Pol. J. Environ. Stud. 23 (5), 1627, 2014.

46. KOSTURKIEWICZ B., JANEWICZ A., MAGDZIARZ A. Results of Briquetting and Combustion Process on BinderFree Coking Coal. Pol. J. Environ. Stud. 23 (4), 1385, 2014.

47. KALEMBKIEWICZ J., CHMIELARZ U. Effects of Biomass Co-Combustion with Coal on Functional Speciation and Mobility of Heavy Metals in Industrial Ash. Pol. J. Environ. Stud. 22 (3), 741, 2013

48. CEIPEK J., KURAZ V., FROUZ J. Hydrological Properties of Soils in Reclaimed and Unreclaimed Sites after BrownCoal Mining. Pol. J. Environ. Stud. 22 (3), 645, 2013.

49. SAHNI A., SARASWATI P.K., RANA R.S., KUMAR K., SINGH H., ALIMOHAMMADIAN H., SAHNI N., ROSE K.D., SINGH L., SMITH T. Temporal constraints and depo- sitional palaeoenvironments of the Vastan lignite sequence, Gujarat: Analogy for the Cambay Shale hydrocarbon source rock. Indian J. Petrol. Geol. 15, 1, 2006.

50. VASSILEV S., KITANO K., VASSILEVA C. Some relationships between coal rank and chemical and mineral composition. Fuel 75, 1537, 1996.

51. ISHAQ M., AHMED I., SHAKIRULLAH M., BAHADUR A., TAJ N. Characterization of Khushab coal (Punjab Pakistan). J. Chem. Soc. Pak. 24 (4), $240,2002$.

52. VASSILEV S., KITANO K., VASSILEVA C. Relations between ash yield and chemical and mineral composition of coals. Fuel 76, 3, 1997

53. FINKELMAN R. The inorganic geochemistry of coal: a scanning electron microscopy view. Scanning Microscopy $2,97, \mathbf{1 9 8 8}$

54. VASSILEV S., TASCON J. Methods for characterization of inorganic and mineral matter in coal: a critical overview. Energy and Fuels 17, 271, 2003.

55. LABAN T., ATKIN C. Regional effects and efficiency of flue gas desulphurization in the Carpathian Basin. Atm. Environ. 41, 8500, 1999.

56. BENABDALLAH N.K., HARRACHE D., MIR A., DE LA GUARDIA M., BENHACHEM F.Z. Bioaccumulation of trace metals by red alga Corallina elongata in the coast of Beni Saf, west coast, Algeria. Chem. Int. 3, 220, 2017.

57. JAFARINEJAD S. Recent developments in the application of sequencing batch reactor (SBR) technology for the petroleum industry wastewater treatment. Chem. Int. 3 (3), 241, 2017.

58. LEGROURI K., KHOUYA E., HANNACHE H., EL HARTTI M., EZZINE M., NASLAIN R. Activated carbon from molasses efficiency for $\mathrm{Cr}(\mathrm{VI}), \mathrm{Pb}$ (II) and $\mathrm{Cu}$ (II) adsorption: A mechanistic study. Chem. Int. 3, 301, 2017.

59. MAJOLAGBE A.O., ADEYI A.A., OSIBANJO O., ADAMS A.O. OJURI O.O. Pollution vulnerability and health risk assessment of groundwater around an engineering Landfill in Lagos, Nigeria. Chem. Int. 3, 58, 2017.

60. OGUNDIPE K.D., BABARINDE A. Comparative study on batch equilibrium biosorption of $\mathrm{Cd}(\mathrm{II}), \mathrm{Pb}$ (II) and $\mathrm{Zn}$ (II) using plantain (Musa paradisiaca) flower: kinetics, isotherm, and thermodynamics. . Chem. Int. 3, 135, 2017.

61. UKPAKA C., IZONOWEI T. Model Prediction on the Reliability of Fixed Bed Reactor for Ammonia Production. Chem. Int. 3, 46, 2017.

62. UKPAKA C.P., IGWE F.U. Modeling of the velocity profile of a bioreactor: the concept of biochemical process. Chem. Int. 3, 258, 2017.

63. ZHANG T., WANG L., HEN Y. Evaluating the Sensitivity of Ecosystems to Soil Salinization in the Manas River Basin. Pol. J. Environ. Stud. 26 (2), 917, 2017. 